\title{
PENCEGAHAN FOODBORNE DISEASE SELAMA PENERBANGAN DENGAN PENERAPAN PRINSIP KEAMANAN PANGAN (FOOD SAFETY) OLEH AWAK KABIN DALAM PESAWAT
}

\author{
Dasti Anditiarina $^{1}$, Sri Wahyuningsih ${ }^{2}$, Ferdi Afian $^{2}$, Wawan Mulyawan ${ }^{3}$ \\ 1. Fakultas Kedokteran Universitas Islam Al-Azhar \\ 2. Program Studi Kedokteran Penerbangan, Departemen Ilmu Kedokteran Komunitas, \\ Fakultas Kedokteran Universitas Indonesia \\ 3. Perhimpunan Dokter Spesialis Kedokteran Penerbangan (PERDOSPI) \\ Email : dastiavmed@gmail.com
}

\begin{abstract}
ABSTRAK
Dengan meningkatnya penggunaan transportasi pesawat udara oleh masyarakat, maka semakin banyak orang yang berpotensi terpapar oleh inflight meal yang tidak higienis. Pelaksanaan protokol hygiene makanan dalam pesawat merupakan faktor yang sangat penting untuk mencegah terjadinya penyebaran penyakit akibat makanan (foodborne disease). Panduan keamanan pangan ini dikeluarkan oleh IFSA (International Flight Services Association) dan AEA (The Association of Europe Airlines) yang merupakan adaptasi dari panduan keamanan pangan dari WHO yang termasuk didalamnya : keterlibatan dari pemangku kebijakan, airline, catering dan juga penyuplai makanan. Kontaminasi dari awak kabin disebabkan karena kegagalan penjamah makanan untuk melakukan cuci tangan yang baik dan benar.
\end{abstract}

Kata Kunci: Penerbangan, Foodborne disease, Food Safety, Kabin.

PENDAHULUAN

Dalam bisnis transportasi penerbangan, salah satu pelayanan maskapai penerbangan kepada penumpang adalah penyediaan inflight meal. Penatalaksanaan inflight meal selama penerbangan sampai saat ini belum diatur oleh aturan yang baku, padahal tingkat kepatuhan untuk melaksanakan langkah langkah kebersihan masih menghadapi hambatan yang nyata seperti sulitnya akses penjamah makanan dalam pesawat terhadap toilet maupun tempat cuci tangan, desain pesawat yang semakin ekonomis karena penambahan jumlah tempat duduk penumpang sehingga mempersempit area dapur pesawat. Padahal menurut data WHO tahun 2015, terdapat sekitar 600 juta penduduk dunia menderita penyakit akibat makanan (food borne disease) dengan angka kematian sekitar 0,007\% (Havelaar, 2010). 
Dengan meningkatnya penggunaan transportasi pesawat udara oleh masyarakat, maka akan semakin banyak pula orang yang berpotensi terpapar oleh inflight meal yang tidak higienis. Apabila foodborne disease didalam pesawat ini dialami oleh pilot maka akan berdampak terhadap keselamatan penerbangan karena pilot dapat mengalami inkapasitasi dan tentu saja hal ini adalah masalah serius (Andrea, 2020).

Pelaksanaan protokol higiene makanan dalam pesawat merupakan faktor yang sangat penting untuk mencegah terjadinya penyebaran penyakit akibat makanan (foodborne disease). Pelaksanaan protokol higiene makanan mungkin tidak akan terkendala apabila dilaksanakan di daratan. Tetapi pada kondisi didalam pesawat yang sedang terbang pasti menimbulkan tantangan tersendiri, belum lagi tingkat kepatuhan yang masih rendah dari penjamah makanan di dalam pesawat untuk melakukan cuci tangan. Beberapa negara mempunyai peraturan yang mendorong agar penjamah makanan di dalam pesawat mempunyai akses yang mudah terhadap tempat cuci tangan dan toilet. Tetapi hal ini belum direspon positif oleh semua maskapai sehingga menimbulkan berbagai tantangan dalam penyediaan makan yang higienis didalam pesawat, seperti minimnya sarana toilet dan tempat cuci tangan untuk para penjamah makanan didalam pesawat (Andrea, 2020).

\section{Foodborne disease}

Food borne disease atau penyakit bawaan makanan adalah penyakit yang disebabkan tertelannya makanan yang sudah terkontaminasi oleh mikroorganisme seperti bakteri, jamur, virus dan juga parasit serta racun alami, bahan kimia dan gen fisik. Penyakit bawaan makanan atau foodborne disease ini adalah salah satu masalah kesehatan yang serius dan mengancam kesehatan masyarakat di seluruh dunia. Baik negara maju maupun negara berkembang memiliki angka kejadian foodborne disease yang sama dan ada kecenderungan mengalami peningkatan insiden dari waktu kewaktu (Mian, 2018).

Beberapa faktor yang mempengaruhi terjadinya foodborne disease adalah 1) patogenitas dari agen penyebab, 2) alat distribusi makanan, 3) Kondisi yang memungkinkan agen patogen untuk hidup, 4) kerentanan dari host.

Permasalahan yang paling menonjol adalah foodborne disease yang disebabkan oleh bakteri, virus dan juga protozoa. Selain itu permasalahan ancaman keamanan pangan berasal dari mikotoxin, residu pestisida, obat-obatan 
hewan ternak, agen agen yang tidak lazim seperti ditemukannya prion yang merupakan bagian dari spongiform encephalopathy dan lingkungan yang tercemar. Faktor faktor yang berperan dalam epidemiologi emerging foodborne disease ini adalah perubahan patogenisitas agen, perkembangan zaman, urbanisasi, dan gaya hidup baru , perubahan sistem kesehatan, perubahan demografi, travelling, dan migrasi, dan lain sebagainya.

Food infection terjadi sebagai akibat dari tertelannya makanan yang mengandung mikrooroganisme patogen seperti virus, bakteri, dan protozoa. Mikroorganisme patogen ini berkembang biak di dalam usus dan menyebabkan penyakit seperti diare, amoebiasis, kolera, dan taeniasis, bahkan bisa menyebabkan zoonotic foodborne disease yaitu anthrax dan bovine tuberculosis.

Food poisoning sendiri terjadi jika kita memakan atau meminum bahan yang sudah terkontaminasi oleh bahan kimia maupun biologi. Sumber kontaminan keracunan makanan ini pada umumnya sudah berada dalam bahan sejak bahan tersebut dipanen. Contoh dari food poisoning ini adalah ; 1. Racun dari bakteri seperti C. Botulinum dan C. perfringens yang secara alami kita temui di tanah. 2. Racun kimia, contohnya insektisida 3. Logam berat seperti
Merkuri, yang terkandung dalam ikan 4 . Racun dari jaringan hewan seperti ikan tertentu, kepiting, dsb.

\section{Higiene Sanitasi Makanan}

Higiene dan sanitasi makanan adalah semua kondisi dan tindakan yang diperlukan untuk memastikan keamanan dan kesesuaian makanan pada setiap tahap rantai makanan. Pengelolaan makanan oleh jasa boga dalam hal ini penyajian inflight meal harus memenuhi higiene dan sanitasi yang dilakukan sesuai cara pengolahan makanan yang baik (PERMENKES RI NO 1096/MENKES/PER/VI/2011 Tentang higiene dan sanitasi jasa boga). Higiene adalah upaya kesehatan dengan cara memelihara dan melindungi kebersihan subjeknya. Sanitasi adalah upaya kesehatan dengan cara memelihara dan melindungi kebersihan lingkungan dari subjeknya.

Tujuan utama Higiene dan Sanitasi yaitu mencegah kontaminasi makanan oleh bakteri, mencegah perkembangbiakan bakteri dan mencegah terjadinya kontaminasi silang dan rekontaminasi. Dasar penyelenggaraan higiene dan sanitasi pangan terdapat dalam: UU NO 18 TAHUN 2012 tentang Pangan pasal 70 dan 71. PP No 28 thn 2004 tentang Keamanan, Mutu dan Gizi Pangan. Keputusan Menteri Kesehatan RI No. 
1209/MENKES/KEP/X/2004 tentang

Persyaratan Kesehatan Lingkungan

Rumah Sakit. PERMENKES RI NO

1096/MENKES/PER/VI/2011 tentang

higiene dan sanitasi jasaboga. UU RI NO

36 Th 2009 tentang Kesehatan.

Terdapat 6 prinsip higiene dan sanitasi makanan yaitu : 1. Pemilihan bahan makanan secara umum dengan memilih makanan yang bersih, tidak berbau, tidak berubah warna serta segar dan tidak berulat untuk sayur- sayuran. Bahan makanan yang dalam bentuk kemasan harus memperhatikan tanggal kadaluwarsanya. 2. Penyimpanan bahan makanan. Bahan makanan yang belum dimasak harus di simpan di lemari pendingin untuk menghindari kerusakan atau pembusukan bahan makanan 3 . Persiapan dan pengolahan makanan Makanan harus diolah dengan alat atau wadah yang bersih, dan tenaga yang mengolah/ menjamah makanan harus menjaga higiene dan sanitasi personalnya yaitu dengan memakai alat pelindung diri (APD) pada saat persiapan, pengolahan makanan bahkan sampai makanan disajikan ke pelanggan. 4. Penyimpanan makanan masak/matang. Makanan matang di simpan dalam wadah yang "Safety", yaitu bersih dan tidak menggunakan wadah yang dapat membahayakan bagi kesehatan. Makanan harus dalam keadaan tertutup, sehingga terhindar dari debu, serangga dan lain-lain 5. Pengangkutan makanan. Pada prinsipnya sama dengan penyimpanan makanan masak/matang dan dalam proses pengangkutan harus menggunakan wadah atau alat yang tidak rawan tumpah. 6. Penyajian makanan. Makanan disajikan dalam wadah yang bersih, tertutup dan pramusaji makanan harus memakai APD sesuai standar. Dengan demikian diharapkan makanan yang disajikan ke pelanggan adalah makanan yang memenuhi syarat kesehatan sehingga dapat bermanfaat untuk kesehatan pelanggan yang mengkonsumsinya (Permenkes RI,. 2011)

\section{Panduan Penyelenggaraan Keamanan Pangan}

Keamanan makanan sudah lama dikenal oleh industri catering pesawat sebagai masalah yang sangat penting dan hal ini merefleksikan catatan keamanan yang sangat baik. Panduan keamanan Pangan ini dikeluarkan oleh IFSA (International Flight Services Association) dan AEA (The Association of Europe Airlines) yang merupakan adaptasi dari panduan keamanan pangan dari WHO yang termasuk didalamnya : keterlibatan dari pemangku kebijakan, airline, catering dan juga penyuplai makanan. Adapun panduan keamanan pangan dari IFSA ini menggunakan pendekatan konsep HACCP (Hazzard 
Critical Control Point) yang selama ini sudah digunakan secara luas di dalam industri pangan. Dalam panduan keamanan pangan dari IFSA ini meliputi: Konsep HACCP, analisa mikroba, Standar Operasional Prosedur penatalaksanaan makanan yang aman.

\section{Penatalaksanaan Makanan Dalam Pesawat}

Belum ada aturan baku terhadap tatalaksana makanan dalam pesawat membuat potensi transmisi foodborne disease dalam pesawat masih tinggi. Meskipun IATA, WHO dan IFSA sudah mengeluarkan panduan terhadap proses tersebut, tetapi masih belum ada metode pengawasan sehingga semua maskapai bisa menaati panduan tersebut. Selain itu belum adanya peraturan yang mewajibkan para penjamah makanan di dalam pesawat dalam hal ini adalah cabin crew untuk mengikuti pelatihan penjamah makanan menyebabkan permasalahan semakin rumit. Ada beberapa aspek dari dimensi higiene makanan dalam pesawat yaitu sumber kontaminasi makanan dalam pesawat, higiene pribadi penjamah makanan dalam pesawat serta hambatan dalam penatalaksanaan makanan yang sehat dan higienis dalam pesawat (Andrea, 2020).

\section{Sumber Kontaminasi Makanan}

Bukti menunjukkan bahwa satu dari lima kasus foodborne disease disebabkan oleh kontaminasi makanan oleh tangan penjamah makanan. Tetapi pada saat di aplikasikan di dalam kabin pesawat maka tidak hanya kontaminasi penjamah makanan saja yang berperan penting munculnya insiden foodborne disease, tetapi desain dapur pesawat juga berdampak pada tatalaksana makanan yang higienis dalam pesawat. Wabah penyakit saluran pencernaan dalam pesawat ditunjukkan adanya muntah di kabin dan toilet. Pada kasus tersebut risiko transmisi infeksi saluran cerna dapat lebih mudah terjadi karena baik penumpang maupun crew pesawat menggunakan toilet yang sama (Andrea, 2020).

Transmisi penyakit yang potensial disebabkan oleh cabin crew dapat digambarkan selama mereka bekerja, dimana transmisi bisa terjadi berulang dari sumber yang sama pada sektor terbang yang beragam. Outbreak penyakit yang disebabkan oleh transmisi langsung terhadap permukaan yang terkontaminasi terjadi beberapa hari setelah insiden kontaminasi dilaporkan. Jenis dan urutan pekerjaan juga menunjukkan perbedaan risiko kontaminasi. Sebagai contoh kegaggalan untuk mencuci tangan setelah menyentuh permukaan tempat kerja yang berdebu 
tampak lebih berisiko dibandingkan jika gagal mencuci tangan setelah menyentuh baju seragam. Kegagalan mencuci tangan setelah menggunakan toilet tampak lebih berisiko jika kegiatan selanjutnya adalah menyiapkan makanan daripada membersihkan toilet. Walaupun penjamah makanan akan dilarang untuk menyediakan makanan pada saat mereka menderita penyakit yang menular, tetapi pada pesawat terbang cabin crew seringkali ditemukan tetap bekerja walaupun sedang dalam keadaan tidak sehat. Cabin crew yang terinfeksi suatu penyakit juga bisa menjadi sumber tranmisi penyebaran penyakit di dalam pesawat (Andrea, 2020).

\section{Higiene Pribadi dan Hambatan Penanganan Makanan}

Menurut WHO, mencuci tangan dengan sabun dan air mengalir merupakan langkah penting untuk mencegah penyebaran infeksi. WHO, IFSA (International Flight Services Agency) dan IATA sudah mengeluarkan panduan penatalaksanaan makanan dalam pesawat secara baik dan higienis. Panduan IFSA didasarkan pada sistem HACCP (Hazzard Analysis and Critical Control Point) yang secara luas dipakai dalam industri makanan dan yang melibatkan identifikasi terhadap ancaman yang spesifik dan merupakan perangkat untuk mengendalikan makanan. Walaupun IATA menegaskan bahwa cabin crew harus mengikuti panduan yang sama dalam penatalaksanaan makanan seperti penatalaksanaan makanan di darat, ada hambatan yang nyata pada saat mereka dalam penerbangan. Untuk cabin crew bisa melakukan hand hygiene yang baik selama penerbangan tergantung pada (1) jumlah fasilitas cuci tangan (2) apakah tempat cuci tangan dekat dengan tempat penyiapan makanan, (3) apakah toilet sedang kosong untuk mencuci tangan (Andrea, 2020).

Penyiapan makan seringkali berhubungan dengan penggunaan toilet oleh penumpang pesawat, sehingga mempersempit kesempatan bagi cabin crew untuk mencuci tangan sebelum menyajikan makanan. Selain itu kombinasi dari keterbatasan waktu dan kurangnya fasilitas adalah hambatan untuk mencuci tangan. Cabin crew bisa mengalami konflik antara keselamatan dan pelayanan yang harus cepat akan menyebabkan kebiasaan yang buruk. Selain itu kendala sempitnya dapur pesawat juga mempermudah terjadinya penatalaksanaan makanan yang buruk. Sebagaimana yang kita ketahui kebanyakan wastafel dalam pesawat tidak didesain untuk mencuci tangan karena keran airnya membutuhkan satu tangan untuk mengoperasikannya. 
Pelatihan Penjamah Makanan Awak Kabin

Selama penerbangan, cabin crew harus mengelola makanan yang berisiko tinggi termasuk salad, ikan dan daging, yang harus disajikan panas ataupun dingin, canapé dan makanan khusus. Tugas yang berkaitan dengan pengelolaan makanan ini jika tidak dilakukakan secara hati-hati bisa menjadi ancaman baik secara biologis, kimia maupun alergi terhadap makanan yang akan disajikan (Daulay, 2019) dan Abdelhakim, 2018). Panduan untuk tatalaksana keamanan makanan tidak sejalan dengan kondisi pada saat penerbangan dan kurang fokus terhadap bahaya yang berkaitan dengan food safety yang harus dijalankan oleh awak kabin. Sehingga hubungan antara awak kabin dan food safety sangat lah erat, dan sampai saat Ini masih menjadi “ missing link".

Awak kabin mempunyai tugas yang berbeda berkaitan dengan penyajian makanan dalam pesawat tergantung pada tipe pesawat, durasi penerbangan, dan faktor faktor lain yang mempengaruhi. Untuk membentuk sistem yang aman dan efektif dalam proses penatalaksanaan makanan dalam pesawat, cabin crew membutuhkan pelatihan tentang food safety yang memadai untuk mengurangi berbagai kemungkinan risiko penyakit akibat makanan ini selama penerbangan Abdelhakim, 2018).

Menurut penelitian tahun 2016, Cabin Crew Food Safety Training: A Qualitative Study, menunjukkan bahwa hampir semua maskapai penerbangan mengikutsertakan awak kabin dalam pelatihan keamanan pangan, tetapi tidak dibedakan sesuai dengan tugas dari awak kabin tersebut dan juga jenis penerbangangnya. Selain itu menurut penelitian tersebut pengetahuan para awak kabin tentang keamanan pangan juga sudah cukup. Tetapi ada hal-hal yang menjadi kendala dalam melaksanakan penanganan makanan yang aman pada saat dalam penerbangan, dengan kendala sebagai berikut : sifat alami dari awak kabin sendiri, ruangan yang sempit, persiapan lanjutan makanan dalam penerbangan, dan desain pesawat yang menyebabkan terbatasnya tempat cuci tangan (Daulay, 2019)

\section{PENUTUP}

Sumber penting foodborne disease didalam pesawat adalah kontaminasi dari penjamah makanan yaitu awak kabin. Kontaminasi dari awak kabin disebabkan karena kegagalan penjamah makanan untuk melakukan cuci tangan yang baik dan benar.

Faktor yang mempengaruhi kegagalan ini adalah : 1. Kurang nya pengetahuan akan pentingnya cuci 
tangan dalam melakukan penyajian makanan; 2. Kurangnya fasilitas cuci tangan didalam pesawat; 3 . Desain dapur pesawat (galley) yang sempit sehingga menyebabkan ruang gerak terbatas dan tangan mudah menyentuh permukaan yang kotor; 4. Belum adanya aturan dan juga panduan yang standar tentang penyajian makanan di dalam pesawat.

Dari keempat permasalahan tersebut bisa dilakukan tindakan perbaikan guna meningkatkan risiko tranmisi foodborne disease didalam pesawat yaitu :

1. Mengikutsertakan para awak kabin dalam pelatihan bagi penjamah makanan, sehingga prosedur penyajian makanan yang sehat dan higienis didalam pesawat dapat ditingkatkan.

2. Penggunaan hand sanitizer dan atau penggunaan sarung tangan pada saat penyajian makanan. Kurangnya fasilitas cuci tangan didalam pesawat dan juga desain dapur yang sempit merupakan hal yang agak sulit untuk dihindari. Terlebih lagi desain pesawat ini merupakan otorita atau kewenangan dari pihak manufature pesawat. Latar belakang terjadinya hal ini adalah persaingan bisnis dari masing masing manufacture dimana mereka berupaya untuk menawarkan keuntungan kepada maskapai dengan menyediakan tempat duduk yang banyak sehingga melupakan kebutuhan akan personal higiene awak kabin. Keadaan ini bisa di atasi dengan menggunakan hand sanitizer, walaupun hal ini masih menjadi perdebatan, karena penggunaan sabun dan air cuci tangan adalah alat utama untuk mencegah penyebaran infeksi.

3. Mendorong pemerintah dan pihak terkait untuk membuat aturan baku terhadap penatalaksanaan makanan yang sehat dan higienis selama dalam penerbangan, yang tentu saja sesuai dengan keterbatasan desain dalam pesawat dan juga kondisi penerbangan yang mempunyai karakteristik khusus, sehingga penatalaksanaan makanan tidak serta merta mengacu pada aturan keamanan makanan di darat.

\section{DAFTAR PUSTAKA}

Abdelhakim.A., Jones.E., Redmond.E., Hewedi.M.,Seaman.P.2018. Cabin Crew Food Safety Training: A Qualitative Study, Food Control, doi: 10.1016/j.foodcont.2018.09.003

Andrea.,G and Elizabeth M. Speakman. 2020. Travel Medicine and Infectious Disease, Inflight transmission of foodborne disease: How can airlines improve.https://doi.org/10.1016/j.tm aid.2020.101558

Daulay, S.S,. 2019. Hazard Analysis Critical Control Point (Haccp) Dan Implementasinya Dalam Industri Pangan. 
Havelaar A.H, Kirk M.D, Torgerson P.R, Gibb H.J, Hald T, Lake R.J,. 2010. On behalf of world health organization foodborne disease burden epidemiology reference group. World health organization global estimates and regional comparisons of the burden of foodborne disease in. PLoS Med 2015;12:e1001923https://doi.org/10. 1016/j.tmaid.2014.11.008

Latiful B,. Sabina Y,. Food Safety and Preservation,. 2018. Handbook of Food Bioengineering Vol 15.

Mian K. S,. Komal J,. Ayesha N,. 2018 . Fooborne Illness: Threath and Control,Foodborne Disease: https://doi.org/10.1016/B978-0-12814956-0.00008-1rvation.

Permenkes RI,. 2011. Higiene dan Sanitasi Jasa Boga. 